DOI 10.31558/2519-2949.2019.2.2

УДК 341.321-056.6

ORCID ID: https://orcid.org/0000-0003-2315-7724

Чайка І. Ю., Запорізький національний університет

ORCID ID: https://orcid.org/0000-0002-7605-0114

Цокур С. Г., Запорізький національний університет

\title{
ДІТИ-КОМБАТАНТИ У ПОСТКОФЛІКТНОМУ ПЕРІОДІ: ПРОБЛЕМА ВІДПОВІДАЛЬНОСТІ І ЗАХИСТУ ПРАВ ДИТИНИ (ЗАРУБІЖНИЙ ДОСВІД ДЛЯ УКРАЇНИ)
}

Використання дітей як учасників збройних конфліктів є найжахливішим проявом дегуманізаиії, коли відбувається порушення невід 'ємних прав людини відносно найбільш уразливих членів суспільства - дітей. Ця проблема не є виключно правовою, хоча й регулюється в достатньо повній мірі Міжнародним гуманітарним правом. Вона поширюється $і$ на сферу моралі, актуалізує питання відтворення суспільства, оскільки діти-комбатанти, зазнаючи руйнівного впливу на власну особистість в процесі ї̈ становлення, переживаючи посттравматичний стресовий розлад, навіть отримуючи потім спеціальну допомогу, у майбутньому навряд чи зможуть розвинутися у повноцінну особистість. Проблема дітей-комбатантів є особливо актуальною для крайн африканського континенту, проте, на жаль, наша держава, починаючи з 2014 р., також вносить свій внесок у изю прикру статистику. Не існує трунтовного, повноцінного дослідження рівня залученості малолітніх та неповнолітніх дітей до збройного конфлікту на Сході Украӥни. Це пояснюється пери за все тим фактом, що у складі регулярних частин Української армії, щео функиіонує на засадах вітчизняного та міжнародного законодавства, немає і не може бути осіб, молодших за 18 років, в той же час дослідження кількості дітей-комбатантів в сепаратистських збройних угрупованнях, російських парамілітарних групах $і$ частинах регулярної армії $Р Ф$, щяо вторглися в нашу державу, з очевидних причин ускладнене. Метою иієї статті є аналіз зарубіжного досвіду створення системи нормативного регулювання та заходів соціальної роботи задля правової та психосочіальної реабілітації дітей-комбатантів. Сучасний зарубіжний досвід створення системи нормативного регулювання та заходів соиіальної роботи задля правової та психосоиіальної реабілітації дітей-комбатантів є иінним для України, як з точки зору використання досягнень, так і в контексті уникнення негативних наслідків. По-перше, важливим $\epsilon$ акиент на необхідності ретельного вивчення в рамках судової процедури причин залучення дитини до участі у збройному конфлікті, суб 'єктів такого залучення, з'ясування конкретних дій, що були вчинені і дитиною, і відносно дитини з їх відповідною правовою кваліфікацією. По-друге, якщо приймається рішення про заходи з покарання дітей-комбатантів, вони мають носити переважно характер пробаиії з обов 'язковою тривалою психосоиіальною реабілітацією. По-третє, надзвичайно важливим є визначення відповідальності батьків дітей-солдатів щуодо неналежного виконання батьківських обов'язків, в тому випадку, якщчо вони мали об' єктивну можливість не залитати дитину на територіях, непідконтрольних Украӥнському уряду.

Ключові слова: діти-солдати, діти-комбатанти, дитина, яка постраждала внаслідок воєнних дій та збройних конфліктів, права дитини.

У XVIII ст. представники просвітницького руху наводили переконливі аргументи на користь того, що збільшення обсягу наукового знання, інтелектуальне зростання людства рано чи пізно трансформується у якісні зміни у сфері людської моралі, знаменуючи повернення до золотого віку моральності і гуманізму. Пройшло більше ніж триста років: наукові досягнення сучасної цивілізації вражають, рівно як вражає і нездатність людства відмовитися від ганебних та жорстоких способів досягати геополітичних, групових i навіть особистісних цілей. Одним з таких, найбільш невідповідних сучасному рівню цивілізаційного розвитку, але надзвичайно життєздатних способів $є$ війна або збройний конфлікт. Світ у XXI ст. $є$ ареною безлічі локальних воєн, до яких залучені в якості безпосередніх учасників, реальних чи потенційних жертв мільйони людей. Учасники збройного протистояння у суспільній свідомості постають переважно як дорослі люди, що мають

Чайка I. Ю., Цокур С. Г., 2019 
особисту мотивацію до такої діяльності. Тим небезпечнішою є тенденція до залучення до збройних конфліктів у якості безпосередніх учасників малолітніх та неповнолітніх дітей. За даними Дитячого фонду $\mathrm{OOH}$, за останнє десятиліття щонайменше 300 тис. дітей-солдат беруть участь у понад 30 конфліктах у різних куточках світу [16]. У 80-ті роки XX ст. до лав народного ополчення Ірану, в ході ірано-іракської війни, було залучено тисячі дітей, яких використовували як озброєних бійців на передовій. В той же час у Іраку в 1991 р. було створено організацію «Левенята Саддама», в яку об'єднали десятки тисяч малолітніх дітей (10-15 років) [10]. Масове використання дітей у якості солдатів вперше в Африці було здійснено у Ліберії, і знову ж таки це були малолітні діти [14, c. 102]. В ході війни між Ефіопією і Ерітреєю (1999-2000 рр.) залучення дітей до участі у воєнних діях набуло характеру мобілізації- дітей забирали зі шкільних лав, озброювали і відправляли на передову. В Уганді формування повстанської армії з дітей відбувалося з 1995 р. 3 того часу діти викрадалися і спрямовувалися до таборів, де їх готували до участі у збройному конфлікті. Загалом постраждало більше 20 тис. дітей (7-15 років), з них 30 \% - дівчатка. Як наслідок, 80\% партизан Уганди - діти. Подібна ж тенденція спостерігалася в Революційному об'єднаному фронті СьєрраЛеоне. Дітей під час збройних конфліктів використовують в різних сферах, які включають як непряму участь (передача воєнної інформації, перевезення зброї) [15, с. 18.], так і фактичну участь (наприклад, вербування інших дітей, включення до активних бойових дій) [12, с. 18].

Використання дітей як учасників збройних конфліктів $є$ найжахливішим проявом дегуманізації, коли відбувається порушення невід’ємних прав людини відносно найбільш уразливих членів суспільства - дітей. Ця проблема не $\epsilon$ виключно правовою, хоча й регулюється в достатньо повній мірі Міжнародним гуманітарним правом. Вона поширюється і на сферу моралі, актуалізує питання відтворення суспільства, оскільки діти-комбатанти, зазнаючи руйнівного впливу на власну особистість в процесі ії становлення, переживаючи посттравматичний стресовий розлад, навіть отримуючи потім спеціальну допомогу, у майбутньому навряд чи зможуть розвинутися у повноцінну особистість.

Зазначені вище факти нібито свідчать про те, що проблема дітей-комбатантів $є$ особливо актуальною для країн африканського континенту, проте, на жаль, наша держава, починаючи з 2014 р., також вносить свій внесок у цю прикру статистику. Не існує грунтовного, повноцінного дослідження рівня залученості малолітніх та неповнолітніх дітей до збройного конфлікту на Сході України. Це пояснюється перш за все тим фактом, що у складі регулярних частин Української армії, що функціонує на засадах вітчизняного та міжнародного законодавства, немає і не може бути осіб, молодших за 18 років, в той же час дослідження кількості дітей-комбатантів в сепаратистських збройних угрупованнях, російських парамілітарних групах і частинах регулярної армії РФ, що вторглися в нашу державу, з очевидних причин ускладнене. Сдиною доступною наразі розвідкою $€$ доповідь Коаліції «Справедливість заради миру на Донбасі». «Принаймні 32 із задокументованих випадків можна кваліфікувати як воєнний злочин відповідно до статті 8 Римського статуту. У 24 випадках вік дітей не перевищував 15 років на момент вербування. У восьми випадках точний вік дітей встановити не вдалося, але є підстави вважати, що ймовірно діти не були старшими 15 років», - йдеться у поданні Коаліції. Дітей залучали для несення служби зі зброєю на блокпостах, використовували як бійців, охоронців, посильних, секретарів. Діти також працювали на кухні. За даними правозахисників, щонайменше 15 незаконних формувань вербували дітей, а саме - бригада «Восток», козача національна гвардія «Всевеликого війська Донського», козачий союз «Область війська Донського», батальйон «Спарта», бригада «Призрак», батальйон «Сомалі», інтернаціональна бригада «Пятнашка», батальйон СРСР «Брянка», «Народне ополчення Донбасу», група швидкого реагування «Бетмен», батальйон «Оплот» [13].

Можна припустити, що фактична кількість дітей-комбатантів на сході України $\epsilon$ значно більшою, і після повернення тимчасово окупованих територій саме перед українським суспільством постане питання щодо відновлення прав дітей-солдатів, їхньої психосоціальної реабілітації, визначення міри їхньої відповідальності за вчинені під час збройного конфлікту дії, а також належного покарання тих, хто сприяв та залучав їх до озброєних формувань. Саме тому необхідним й актуальним $\epsilon$ вивчення міжнародного досвіду подолання наслідків участі дітей у воєнних конфліктах в якості комбатантів.

Метою цієї статті є аналіз зарубіжного досвіду створення системи нормативного регулювання та заходів соціальної роботи задля правової та психосоціальної реабілітації дітей-комбатантів.

Особливості захисту різних категорій суб'єктів в період воєнних конфліктів розглядалися в роботах багатьох вітчизняних та зарубіжних досілдників, зокрема: А. Амеліна, А. Альошина, I. Арцибасова, В. Батиря, П.Бірюкова, Е. Волоха, А. Григор'єва, С. Сгорова, Ф. Кальсховена, 
В. Калугіна, І. Котлярова, Ф. Кожевникова, В. Лісовського, С. Леншина, Г. Мелкова, В. Мицика, А. Полторака, В. Репецького, Л. Савинського, Л. Савчука, Д. Самодурова, О. Тіунова, Л. Тимченка. Однак, увага саме до проблеми захисту прав дітей-комбатантів приділялася в роботах лише деяких науковців (К. Барстад, В. А. Захарія, Л. В. Корбут, Ф. Крілль, К. Ніконов, Н. Петрова, Д. Платтнер, Ж. Стефан).

Перед тим як розглянути особливості правового регулювання проблеми дітей-комбатантів та діяльності держав із соціального захисту дітей-солдатів варто згадати міжнародні нормативні акти, які врегульовують деякі з цих питань.

Вперше в тексті міжнародно-правового акту поняття дітей, які беруть участь у військових діях, 3'являється лише в 1977 р. при складанні Додаткових протоколів до Женевських конвенцій про захист жертв війни. Додатковий протокол I, застосовуваний в період міжнародних збройних конфліктів (далі - ДП I), зобов’язує держави вживати «усіх практично можливих заходів для того, щоб діти, які не досягли п’ятнадцятирічного віку, не брали безпосередньої участі у воєнних діях...», утримуватися «від вербування їх у свої збройні сили», і наполегливо рекомендується державамучасницям при вербуванні з числа осіб, які досягли 15-річного віку, але яким ще не виповнилося 18 років, віддавати перевагу особам більш старшого віку (ст. 77 (2)) [3]. Норми Додаткового протоколу II, що застосовується в період збройних конфліктів неміжнародного характеру (далі ДП II), несуть більш безумовний характер, ніж норми ДП І. Згідно ДП ІІ, «діти, які не досягли п'ятнадцятирічного віку, не підлягають вербуванню у збройні сили або групи і їм не дозволяється брати участь у військових діях» (ст. 4 (3) (c)) [4]. За дітьми, які беруть безпосередню участь в міжнародних збройних конфліктах, визнається статус комбатанта i, в разі захоплення, статус військовополоненого. Основним міжнародно-правовим документом, що визначає режим військового полону, $є$ Женевська конвенція про поводження з військовополоненими 1949 р. Відповідно до додаткових протоколів діти-комбатанти, які не досягли 15 років, мають право на більш сприятливе поводження, оскільки вони продовжують користуватися особливим захистом, що надається дітям міжнародним гуманітарним правом (ДП I, ст. 77 (3); ДП II, ст. 4 (3 ) (d) (1).

Також норми, що стосуються захисту дітей під час збройного конфлікту, містяться в Конвенції про права дитини 1989 р. і Факультативному протоколі до Конвенції про права дитини. Відповідно до ст. 38 Конвенції, держави-учасниці мають вжити всіх можливих заходів для забезпечення того, щоб особи, які не досягли п'ятнадцятирічного віку, не брали безпосередньої участі у воєнних діях (ст. 38 (2)) [5], а при вербуванні з числа осіб, які досягли 15-річного віку, але яким ще не виповнилося 18 років, прагнути віддавати перевагу особам більш старшого віку (ст. 38 (3)) [5], таким чином дія ст. 77 ДП І поширюється на неміжнародні збройні конфлікти. 12 лютого 2002 р. набрав чинності Факультативний протокол до Конвенції про права дитини щодо участі дітей у збройних конфліктах (прийнятий резолюцією 54/263 Генеральної Асамблеї від 25 травня 2000 р.). Цей Факультативний протокол був прийнятий з метою сприяння більш ефективному здійсненню прав, визнаних у Конвенції про права дитини, шляхом посилення захисту дітей від участі в збройних конфліктах. У ст. 4 закріплюється положення про те, що збройні групи, відмінні від збройних сил держави, за жодних обставин не повинні вербувати (як на примусовій, так i на добровільній основі) або використовувати у військових діях осіб, які не досягли 18-річного віку. У свою чергу, державам слід вживати законодавчих заходів щодо заборони подібної практики і криміналізувати іiі [6].

Спираючись на ці міжнародні нормативні акти та національне законодавство, різні держави вирішували проблему дітей-комбатантів.

Варто сказати, що по відношенню до дітей-солдатів в міжнародному праві не існує положень, що виключають кримінальне переслідування. Проте робиться застереження щодо того, що відповідальність повинна оцінюватися відповідно до віку, а заходи відповідальності повинні нести швидше виховний, ніж каральний характер [11, с. 76.]. Крім того, не можна забувати про принцип невинесення і незастосування страти по відношенню до дітей (стаття 77 Першого Додаткового Протоколу).

В Африці розгляд справ дітей-солдатів, які вчинили міжнародні злочини, здійснювався із застосуванням різних підходів і приводило до найрізноманітніших результатів. У 1995 р. директор неурядової ліберійської організації Комісія за справедливість і мир С. К. Вудс так охарактеризував позицію ліберійського суспільства 3 питання про кримінальну відповідальність дітей-солдатів: «Ні в минулі роки, ні в даний час жодна дитина-солдат ніколи не була звинувачена та не піддавалася переслідуванню за участь в скоєнні злочинів під час нашої громадянської війни. Наше суспільство 
не бажає карати дітей, причетних до злочинів. Як правило, люди вважають, що краще їх реабілітувати». При обгрунтуванні цієї позиції він наводив аргументи юридичного та культурного характеру: «Небажання порушувати переслідування проти дітей відповідає Конвенції про права дитини та нашим національним законам, згідно з якими до досягнення повноліття вони не відповідають за свої дії. 3 точки зору культурних традицій, відповідальність за злодіяння повинна бути покладена, в першу чергу, не на самих дітей, а на їхніх батьків або тих, хто підштовхнув їх до скоєння злочинів». Мабуть, до амністії, принаймні фактичної, схиляється і Демократична Республіка Конго.

31994 р. в Руанді існує дисбаланс між рішучістю домогтися того, щоб справедливість звершилася для жертв геноциду, і обмеженими можливостями судової системи. Щоб покінчити 3 безкарністю і забезпечити швидкий розгляд справ, в 1996 р. був прийнятий перший органічний закон про організацію судового переслідування осіб, обвинувачених у вчиненні злочину геноциду або злочинів проти людяності. Для розгляду справ звинувачених і застосування нового порядку провадження в судах першої інстанції і військових трибуналах були створені спеціалізовані палати. Органічний закон 1996 р. передбачав введення до складу останніх трьох суддів у справах неповнолітніх для здійснення правосуддя щодо даної категорії правопорушників. Органічний закон 1996 р. не приніс очікуваних результатів. Остаточно 1999 р. через спеціалізовані палати, які були створені для розгляду справ про злочини, пов'язані з геноцидом, пройшли лише 2406 чоловік, в той час як 121500 осіб, у тому числі 4454 дитини, залишалися в різних місцях утримання під вартою. В результаті для заміни охарактеризованого вище механізму була створена система народних судів гачача. При цьому система судів гачача не передбачає ніяких спеціальних процесуальних гарантій для дітей. До дітей, обвинувачених у злочині геноциду або злочинах проти людяності, яким в момент вчинення правопорушення було від 14 до 18 років, застосовуються ті ж процесуальні норми, що і до дорослих, вони постають перед тими ж судами, що і повнолітні, і можуть розраховувати на особливе поводження (пом'якшення покарання) лише в кінці процесу, якщо вони визнані винними і засуджені [7].

Для постконфліктного врегулювання в Сьєрра-Леоне у 2000 р. ООН створила Спеціальний суд із Сьєрра-Леоне. Суд був наділений обмеженою юрисдикцією щодо осіб старше 15 років і передбачав, що при поводженні з особами у віці від 15 до 18 років будуть враховуватися їхня молодість, бажаність їх реабілітації та міжнародні норми в області прав дитини. Нарешті, Статут Суду виключав призначення покарань, що представляють собою чисто репресивні заходи у вигляді позбавлення волі, віддаючи перевагу заходам реабілітації та реінтеграції в суспільство. Крім того Статут Суду регламентував діяльність Комісії із встановлення істини і примирення. У практичному плані рішення про те, карати або не карати дітей, було залишено на розсуд обвинувача. Справді, Обвинувач Суду Девід Крейн неодноразово заявляв, що жодна дитина не буде переслідуватися в судовому порядку, і що стратегія його Канцелярії, скоріше, полягає в тому, щоб судити осіб, відповідальних за вербування та використання дітей. У той же час свідчення великої кількості дітей - як потерпілих, так і злочинців - були заслухані в Комісії із встановлення істини i примирення [7].

Заходи правового характеру відносно дітей-комбатантів доповнюються системою психосоціальної реабілітації. Як правило, національні уряди в ході організації та фінансування цих процесів спираються на допомогу міжнародних організацій, перш за все UNICEF.

В Південному Судані, де з початку конфлікту в 2013 р. близько 19 тисяч дітей були викрадені бойовиками, створена школа UNICEF з реінтеграції колишніх солдатів з числа неповнолітніх. Дітей навчають читання та письма, здійснюють професійну підготовку, щоб підвищити їхню спроможність на ринку праці. Дехто з учнів школи вимагає тривалої психосоціальної реабілітації, оскільки не розглядає свій досвід в якості комбатанта, як негативне явище. Одна з вихованок школи заявила: «Мені подобалося мати при собі зброю і бути солдатом. Була якась мета, була щоденна робота. Я хочу бути солдатом, у якого є зброя, влада і робота» [8].

В Уганді колишніх дітей-солдатів з повстанської «Армії супротиву Бога», що мають аналогічну не пропрацьовану воєнну психотравму, після вилучення з лав цієї організації заохочують до служби в урядових військах. Останні 19 років уряд Уганди веде війну з «Армією опору Бога». Це незаконне угруповання систематично викрадає дітей для залучення їх до бойових дій та використання в якості слуг і сексуальних рабів. Всього було викрадено понад 20 тисяч хлопчиків і дівчат. Багатьом з них на момент викрадення було не більше 7-8 років. Виконавчий директор Дитячого фонду ООН у 19952005 рр. К. Белламі назвала війну на півночі Уганди «війною проти дітей» і закликала всю 
міжнародна спільнота «не закривати очі на те, що відбувається». Завдяки зусиллям агентств і фондів $\mathrm{OOH}$, а також їхніх партнерів з неурядових організацій багато з цих дітей були демобілізовані. UNICEF наголошує, що ті, хто був викрадений «Армією опору Бога», достатньо настраждалися i потребують інтенсивної реабілітації. Прагнення цих дітей служити в армії пояснюється тим, що вони більше нічого не вміють. Крім того, їм не пропонують жодних альтернатив і не допомагають інтегруватися в мирне життя [9].

Необхідно зазначити, що українське законодавство наразі вже містить певні норми, що можуть бути використані під час вирішення питання дітей-солдатів. Зокрема, у ст. 30 Заборона участі дітей у воєнних діях і збройних конфліктах Закону України «Про охорону дитинства» зазначається: «Участь дітей у воєнних діях і збройних конфліктах, включаючи вербування, фінансування, матеріальне забезпечення, навчання дітей з метою використання узбройних конфліктах інших держав або насильницьких діях, спрямованих на повалення державної влади чи порушення територіальної цілісності, а також використання дітей у воєнних діях і збройних конфліктах, залучення та/або втягування дітей до не передбачених законами України воєнізованих чи збройних формувань, пропаганда війни забороняються... Особи, винні у порушенні вимог частини першої цієї статті, несуть кримінальну відповідальність, встановлену законом» [1]. Особи, що здійснюють вербування малолітніх та неповнолітніх до озброєних угруповань несуть відповідальність за ст. 304 Кримінального кодексу України «Втягнення неповнолітніх у злочинну діяльність», за «втягнення неповнолітніх у злочинну діяльність, у пияцтво, у заняття жебрацтвом, азартними іграми», що карається позбавленням волі на строк від трьох до семи років. Водночас, наявними $є$ норми Кримінального Кодексу, що можуть бути використані для покарання неповнолітніх осіб віком від чотирнадцяти до шістнадцяти років, що вчинили злочини, за диверсію (ст. 113); шпигунство (ст. 114); терористичний акт (ст. 258); пошкодження шляхів сполучення і транспортних засобів (ст. 277); посягання на життя представника правоохоронного органу, члена громадського формування 3 охорони громадського порядку і державного кордону або військовослужбовця (ст. 348). В той же час, у ст. $30^{-1}$ Захист дітей, які перебувають у зоні воєнних дій і збройних конфліктів, та дітей, які постраждали внаслідок воєнних дій і збройних конфліктів ЗУ «Про охорону дитинства» міститься норма, що «центральний орган виконавчої влади, що забезпечує формування та реалізує державну політику з питань сім'ї та дітей, центральний орган виконавчої влади, що забезпечує формування та реалізує державну політику у сферах освіти і науки, центральний орган виконавчої влади, що забезпечує формування та реалізує державну політику у сфері охорони здоров'я, створюють умови для медичної, психологічної, педагогічної реабілітації та соціальної реінтеграції дітей, які постраждали внаслідок воєнних дій i збройних конфліктів. Статус дитини, яка постраждала внаслідок воєнних дій і збройних конфліктів, надається органом опіки та піклування за місцем реєстрації дитини як внутрішньо переміщеної особи» [1]. У відповідності ж до Порядку надання статусу дитини, яка постраждала внаслідок воєнних дій та збройних конфліктів, такий статус надається i дитині, а також особі, яка під час здійснення антитерористичної операції не досягла 18 років (повноліття), які внаслідок воєнних дій та збройних конфліктів залучалися до участі у діях воєнізованих чи збройних формувань [2]. Таким чином, дитина-комбатант виявляється одночасно i суб'єктом злочину, і постраждалим від цього злочину, і особою, яка має особливий статус постраждалої внаслідок воєнних дій та збройних конфліктів. Ці факти свідчать про необхідність перегляду вітчизняного законодавства задля забезпечення дотримання балансу прав дитиникомбатанта і відповідальності за її дії, вчинені під час збройного конфлікту.

Очевидно, що сучасний зарубіжний досвід створення системи нормативного регулювання та заходів соціальної роботи задля правової та психосоціальної реабілітації дітей-комбатантів $є$ цінним для України, як з точки зору використання досягнень, так і в контексті уникнення негативних наслідків. По-перше, важливим $є$ акцент на необхідності ретельного вивчення в рамках судової процедури причин залучення дитини до участі у збройному конфлікті, суб'єктів такого залучення, 3'ясування конкретних дій, що були вчинені і дитиною, і відносно дитини з їх відповідною правовою кваліфікацією. По-друге, якщо приймається рішення про заходи з покарання дітейкомбатантів, вони мають носити переважно характер пробації з обов'язковою тривалою психосоціальною реабілітацією. По-третє, надзвичайно важливим є визначення відповідальності батьків дітей-солдатів щодо неналежного виконання батьківських обов'язків, в тому випадку, якщо вони мали об'єктивну можливість не залишати дитину на територіях, непідконтрольних Українському уряду. 


\section{Бібліографічний список:}

1. Про охорону дитинства: Закон України від 26.04.2001 № 2402-III. URL: https://zakon.rada.gov.ua/laws/show/2402-14. (дата звернення: 29.03.2019).

2. Порядок надання статусу дитини, яка постраждала внаслідок воєнних дій та збройних конфліктів: затверджений постановою Кабінету Міністрів України від 5.04.2017 p. № 268. URL: https://zakon.rada.gov.ua/laws/show/268-2017-п. (дата звернення: 29.03.2019).

3. Дополнительный протокол к Женевским конвенциям от 12 августа 1949 г., касающийся защиты жертв международных вооруженных конфликтов (Протокол I). Женева, 8.06.1977 г.

URL: https://www.icrc.org/ru/doc/assets/files/2013/ap_i_rus.pdf. (дата звернення: 29.03.2019).

4. Дополнительный протокол к Женевским конвенциям от 12 августа 1949 г., касающийся защиты жертв вооруженных конфликтов немеждународного характера (Протокол II). Женева, 8.06.1977 г.

URL: https://www.icrc.org/ru/doc/resources/documents/misc/6lkb3l.htm. (дата звернення: 29.03.2019).

5. Конвенция о правах ребенка. Принята резолюцией 44/25 Генеральной Ассамблеи от 20.11.1989 г.

URL: https://www.un.org/ru/documents/decl_conv/conventions/childcon.shtml. (дата звернення: 29.03.2019).

6. Факультативный протокол к Конвенции о правах ребенка, касающийся участия детей в вооруженных конфликтах Принят резолюцией 54/263 Генеральной Ассамблеи от 25.05.2000 г.

URL: https://www.un.org/ru/documents/decl_conv/conventions/rightschild_protocol1.shtml. (дата звернення: 29.03.2019).

7. Арзуманян Н., Пиццутелли Ф. Жертвы и палачи: вопросы ответственности, связанные с проблемой детей-солдат в Африке. Международный Журнал Красного Креста. 2003. № 852. С.429-462.

8. Будете плакати - вб'ємо: діти, завербовані в солдати, згадують про пережиті звірства.

URL: https://trueua.info/news/budete-plakati--vbyemo-diti-zaverbovani-v-soldati-zgaduyut-pro-perezhiti-zvirstva. (дата звернення: 29.03.2019).

9. Бывшие угандийские дети-комбатанты опять идут в армию, но уже в правительственную.

URL: https://news.un.org/ru/story/2005/02/1065941. (дата звернення: 29.03.2019).

10. Галанцев В. Хто він, малюк 3 «калашем»? Військо Украӥни. 2004. №9-10. С.23-25.

11. Дутли М.Т. Дети-комбатанты, захваченные в плен. Дети и война: сб. статей. Москва: МККК, 1995. C.64-80.

12. Платтнер Д. Защита детей в международном гуманитарном праве. Дети и война: сб. статей. Москва: МККК, 1995. С.5-20.

13. Правозахисники зафіксували 95 випадків, коли дітей залучали до збройного конфлікту на Донбасі. URL: https://forbiddentoforbid.org.ua/uk/pravozakhisniki-zafiksuvali-95-vipadki/. (дата звернення: 29.03.2019).

14. Френкель М. Гражданская война в Либерии. Международная экономика и международные отночения. 1998. № 7. С. 102-109.

15. Kumar K. Civil War, Women and Gender Relations: An Overview. Woman and civil war: Impact, Organisation and action. London: Boulder, 2001. P. 5-79.

16. UNICEF. A major step to end the use of child soldiers. URL:www.unicef.org/noteworthy/protocol-conflict/. (дата звернення: 29.03.2019).

\section{References:}

1. Pro okhoronu dytynstva: Zakon Ukrayiny vid 26.04.2001 № 2402-III.

URL: https://zakon.rada.gov.ua/laws/show/2402-14. (data zvernennya: 29.03.2019).

2. Poryadok nadannya statusu dytyny, yaka postrazhdala vnaslidok voyennykh diy ta zbroynykh konfliktiv: zatverdzhenyy postanovoyu Kabinetu Ministriv Ukrayiny vid 5.04.2017 p. № 268. URL: https://zakon.rada.gov.ua/laws/show/268-2017-п. (data zvernennya: 29.03.2019).

3. Dopolnitel'nyy protokol k Zhenevskim konventsiyam ot 12 avgusta 1949 g., kasayushchiysya zashchity zhertv mezhdunarodnykh vooruzhennykh konfliktov (Protokol I). Zheneva, $8.06 .1977 \mathrm{~g}$.

URL: https://www.icrc.org/ru/doc/assets/files/2013/ap_i_rus.pdf. (data zvernennya: 29.03.2019).

4. Dopolnitel'nyy protokol k Zhenevskim konventsiyam ot 12 avgusta 1949 g., kasayushchiysya zashchity zhertv vooruzhennykh konfliktov nemezhdunarodnogo kharaktera (Protokol II). Zheneva, 8.06.1977 g.

URL: https://www.icrc.org/ru/doc/resources/documents/misc/6lkb31.htm. (data zvernennya: 29.03.2019).

5. Konventsiya o pravakh rebenka. Prinyata rezolyutsiyey 44/25 General'noy Assamblei ot 20.11.1989 g. URL: https://www.un.org/ru/documents/decl_conv/conventions/childcon.shtml. (data zvernennya: 29.03.2019).

6. Fakul'tativnyy protokol $\mathrm{k}$ Konventsii o pravakh rebenka, kasayushchiysya uchastiya detey v vooruzhennykh konfliktakh Prinyat rezolyutsiyey 54/263 General'noy Assamblei ot 25.05.2000 g. URL: https://www.un.org/ru/ documents/decl_conv/conventions/rightschild_protocol1.shtml. (data zvernennya: 29.03.2019).

7. Arzumanyan N., Pitstsutelli F. Zhertvy i palachi: voprosy otvetstvennosti, svyazannyye s problemoy deteysoldat v Afrike. Mezhdunarodnyy Zhurnal Krasnogo Kresta. 2003. № 852. S.429-462.

8. Budete plakaty - vb"yemo: dity, zaverbovani v soldaty, z haduyut' pro perezhyti zvirstva. URL: https://trueua.info/news/budete-plakati--vbyemo-diti-zaverbovani-v-soldati-zgaduyut-pro-perezhiti-zvirstva. (data zvernennya: 29.03.2019).

9. Byvshiye ugandiyskiye deti-kombatanty opyat' idut $\mathrm{v}$ armiyu, no uzhe $\mathrm{v}$ pravitel'stvennuyu.

URL: https://news.un.org/ru/story/2005/02/1065941. (data zvernennya: 29.03.2019). 
10. Halantsev V. Khto vin, malyuk z «kalashem»? Viys'ko Ukrayiny. 2004. №9-10. S.23-25. S.64-80

11. Dutli M.T. Deti-kombatanty, zakhvachennyye v plen. Deti i voyna: sb. statey. Moskva: MKKK, 1995.

12. Plattner D. Zashchita detey v mezhdunarodnom gumanitarnom prave. Deti i voyna: sb. statey. Moskva: MKKK, 1995. S.5-20.

13. Pravozakhysnyky zafiksuvaly 95 vypadkiv, koly ditey zaluchaly do zbroynoho konfliktu na Donbasi. URL: https://forbiddentoforbid.org.ua/uk/pravozakhisniki-zafiksuvali-95-vipadki/. (data zvernennya: 29.03.2019).

14. Frenkel' M. Grazhdanskaya voyna v Liberii. Mezhdunarodnaya ekonomika i mezhdunarodnyye otnosheniya. 1998. № 7. S. 102-109.

15. Kumar K. Civil War, Women and Gender Relations: An Overview. Woman and civil war: Impact, Organisation and action. London: Boulder, 2001. P. 5-79.

16. UNICEF. A major step to end the use of child soldiers. URL:www.unicef.org/noteworthy/protocol-conflict/. (data zvernennya: 29.03.2019).

Chaika I. Yu., Tsokur Ye. G. Children-combatants in the post-coflict period: the problem of liability and protection of child rights (international experience for Ukraine)

The use of children as participants in armed conflicts is the worst manifestation of dehumanization, when there is a violation of the inalienable human rights of the most vulnerable members of societychildren. This problem is not exclusively legal, although it is fully regulated by international humanitarian law. It extends to the sphere of morality and actualizes the question of the reproduction of society, since children-combatants, having experienced devastating influence on their own personality in the process of its formation, experiencing post-traumatic stress disorder, even receiving special assistance then, in the future, unlikely to be able to develop into a full-fledged personality. The problem of child combatants is especially relevant for the African continent, but unfortunately our state, since 2014, also contributes to this cumbersome statistics. There is no thorough, full-fledged study of the level of involvement of juvenile and minor children in the armed conflict in the East of Ukraine. This is primarily due to the fact that, as part of the regular units of the Ukrainian Army operating on the basis of domestic and international law, there are no and there can be no young people under the age of 18, at the same time, the study of the number of combatants in separatist armed groups, Russian paramilitary groups and parts of the regular army of the Russian Federation, which invaded our state, for obvious reasons, is complicated. The purpose of this article is to analyze the foreign experience of creating a system of normative regulation and measures of social work for legal and psychosocial rehabilitation of children-combatants. The current foreign experience of establishing a system of normative regulation and social work activities for the legal and psychosocial rehabilitation of child combatants is valuable for Ukraine both in terms of using achievements and in the context of avoiding negative consequences. Firstly, it is important to emphasize the need for careful study in the judicial process of the reasons for involving the child in participation in an armed conflict, the subjects of such involvement, ascertaining the concrete actions that were committed and the child, and in relation to the child with their respective legal qualifications. . Secondly, if a decision is made on measures to punish children-combatants, they should be mainly the nature of probation with compulsory long-term psychosocial rehabilitation. Thirdly, it is extremely important to determine the responsibility of parents of child soldiers for improper performance of parental responsibilities, in the event that they had an objective opportunity not to leave the child in territories not under the control of the Ukrainian government.

Key words: child soldiers, children-combatants, a child who has suffered as a result of hostilities and armed conflict, the rights of the child. 